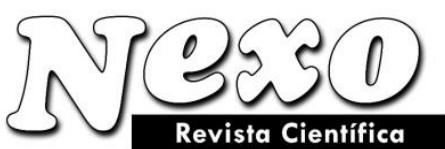

Vol. 33, No. 02, pp. 223-238/Diciembre 2020
ISSN-E 1995-9516

Universidad Nacional de Ingeniería COPYRIGHT @ (UNI). TODOS LOS DERECHOS RESERVADOS http://revistas.uni.edu.ni/index.php/Nexo https://doi.org/10.5377/nexo.v33i02.10764

\title{
Examination of alteration and metasomatic zones based on the tectonic setting of the Kamoo region (northeast of Isfahan, Iran)
}

\section{Examen de alteración y zonas metasomáticas basadas en la configuración tectónica de la región Kamoo (noreste de Isfahán, Irán)}

\author{
Manouchehr Alahbakhshi ${ }^{1}$, Reza Mehrnia ${ }^{* 2}$, Mohammad Reza Espahbod ${ }^{3}$, Afshin Ashja- \\ $\operatorname{Ardalan}^{4}$
}

1 Department of Geology, North Tehran Branch, Islamic Azad University, Tehran, Iran. CP: 44531-67779, Tel.: (+98) 9113363219 - ma1057974@gmail.com, http://orcid.org/ 0000-0002-2870-4910

2 Department of Geology, Payam Noor University, Iran. CP: 16746-88317, Tel.: (+98)

9122574607 - *Corresponding author: srmehrnia@ yahoo.com, http://orcid.org/ 00000001-9801-4707

3 Department of Geology, North Tehran Branch, Islamic Azad University, Tehran, Iran. CP: 14558-34935, Tel.: (+98) 9128437941-dr.espahbod@ gmail.com, http://orcid.org/ 0000-0002-0000-9326

4 Department of Geology, Islamic Azad University, North Tehran Branch, Tehran, Iran. CP: 165115-3311. Tel: (+98) 9122251562-afshinashjaardalan@yahoo.com, http://orcid.org/ 0000-0002-1800-9594

(recibido/received: 01-April-2020; aceptado/accepted: 18-June-2020)

\begin{abstract}
Kamoo region (northeast of Isfahan) has an anticline structure with a northwest-southeast trend. The exposed part of this anticline consists of siltstone-sandstone and Jurassic shale, which is located below the Cretaceous formation as an unconformity. Penetration by magmatic masses (dikes) and mineralization events are mainly related to fault systems and fractures in the region and follow the trend of the anticline. In addition, the intensity and variety of alterations are affected by tectonic factors, with alteration and metasomatic haloes having developed next to crushed areas. The alteration process is the main controller of mineral mass grade in the study area; therefore, iron grade in the Kamoo ore has increased by the effects of alteration. The alteration effects include propylitic haloes, iron hydroxides (limonite), and clay mineralization (argillic). The host rock consists of Jurassic shales with siltstone, sandstone, and Cretaceous limestone. Calcareous formations adjacent to granodiorite masses are the main hosts of iron skarns. The results of this study showed that the mineral samples from Kamoo were relatively rich in Light Rare Earth Elements (LREEs); the average $\mathrm{La} / \mathrm{Yb}$ ratio is about 18.61 and Eu anomaly is between 0.52 and 1.94. Based on the findings of this study, the origin for Kamoo skarn was consistent with the model presented by
\end{abstract}


Meinert, and the region's mineralization and alteration characteristics correspond to the conditions prevailing in oceanic subduction and back-arc basin environments.

Keywords: Alteration, Kamoo, Rare Elements, Skarn Formation.

\section{RESUMEN}

La región de Kamoo (noreste de Isfahan) tiene una estructura anticlinal con una tendencia noroestesureste. La parte expuesta de este anticlinal consiste en arenisca-arenisca y lutita jurásica, que se encuentra debajo de la formación del Cretácico como una disconformidad. La penetración por masas magmáticas (diques) y los eventos de mineralización están relacionados principalmente con sistemas de fallas y fracturas en la región y siguen la tendencia del anticlinal. Además, la intensidad y la variedad de las alteraciones se ven afectadas por factores tectónicos, con la alteración y los halos metasomáticos que se han desarrollado junto a las áreas trituradas. El proceso de alteración es el controlador principal del grado de masa mineral en el área de estudio; por lo tanto, el grado de hierro en el mineral de Kamoo ha aumentado por los efectos de la alteración. Los efectos de alteración incluyen halos propilíticos, hidróxidos de hierro (limonita) y mineralización de arcilla (argílica). La roca huésped consiste en lutitas jurásicas con limolita, arenisca y caliza cretácea. Las formaciones calcáreas adyacentes a las masas de granodiorita son los principales anfitriones de los skarns de hierro. Los resultados de este estudio mostraron que las muestras minerales de Kamoo eran relativamente ricas en elementos de tierras raras ligeras (LREE); la relación media de La / Yb es de aproximadamente 18,61 y la anomalía de Eu es de entre 0,52 y 1,94. Según los hallazgos de este estudio, el origen de Kamoo skarn fue consistente con el modelo presentado por Meinert, y las características de mineralización y alteración de la región corresponden a las condiciones que prevalecen en los entornos de subducción oceánica y cuenca de arco posterior.

Palabras clave: Alteración, Kamoo, Elementos raros, Formación de Skarn.

\section{INTRODUCCIÓN}

The host rock of hydrothermal deposits often has obvious reactionary effects, which occur in the path of faults and connecting channels due to the tendency of hot fluids to balance with the surrounding rocks. During this process, the hot fluid adapts to the new conditions and an insulation layer is formed between the surrounding rock and the ore-bearing solution in fault channels, which is referred to as the wall alteration phenomenon. The volume or surface area occupied by the alteration minerals is called the alteration halo (Gilbert and Park, 2007). The type of chemicals and mineralogical changes at alteration halos depend on the physicochemical conditions of the hydrothermal solution and the mineralogical composition of the host rock. The chemical composition of hydrothermal or magmatic solution, temperature, depth, acidity, and oxidation-reduction conditions play an important role in alteration zones. Furthermore, the intensity and expansion of alteration indicate the expansion of mineralization in a region. Expansion of mineralization depends on various factors such as the volume of hydrothermal or magmatic solutions, the amount of useful primary and secondary structures, the reactivity of rocks, and temperature and pressure of the solution (Pirajno, 2009). Alteration halos are used to locate mineral potential by the geochemical method. In addition, it is possible to use alteration effects and their mineral content after the introductory phases to determine the type of mineralization and expansion mechanism and setting of the mineralization zone (Najafzadeh et al., 2011, Yazdi et al., 2019, Fakhari et al., 2019). There is a direct relationship between the extent of alterations and the extent of mineralization. The shape of the alteration zones is a good guide for determining the geometric shape and structure of mineralization (Karimpour and Saadat., 2003). During the Kamoo field studies, some alteration halos were identified and separated, and limited lithogeochemical sampling was used to prepare microscopic sections and perform chemical analyses in order to complete the studies and interpret the data. 
According to field observations, alteration facies of Kamoo include oxides, iron hydroxides (hematite, goethite), and propylitic, sericite, and clay minerals (kaolinite), which are very important in the formation of iron ores. Based on petrographic and geochemical field evidence, the regions has a collection of primary minerals including chalcopyrite, pyrite, marcasite and magnetite, and secondary minerals such as malachite, bornite, covellite, chalcocite, hematite, goethite, and hydrous ferric oxides of surface and secondary origins. This study aims to provide new information about the occurrence of alteration and metasomatic zones and their relationship with the tectonics of the Kamoo region based on field observations, geochemical analyses, and microscopic studies.

\section{METHODOLOGY}

This study has been done in two sections: a field section and a laboratory section. In the field, surveys were conducted in several stages to identify the stratigraphic units and the type and extent of alteration zones. Then, based on the field observations, samples were taken from different alteration zones and related igneous rocks. In the laboratory, 10 samples were selected for thin and polished sections and 11 samples were selected for device analysis. The samples were ground into a powder with dimensions smaller than 10 $\mu \mathrm{m}$ by an agate mortar. X-ray diffraction (XRD) analysis was performed using the Bruker D8 ADVANCE diffractometer in the laboratory of Azarine Zamin Azma Sorena Company located in Fars Science and Technology Park, Iran. In addition, 10 samples were sent to Canada for inductively coupled plasma mass spectrometry (ICP-MS) and to identify secondary and rare elements. Given the role of satellite information in identifying and separating stratigraphic units and alteration effects, remote sensing studies in Kamoo were performed by processing ASTER images in ENVI and Geomatica. The different bands provided by this sensor were used to identify alteration zones and their relationship with faults in the region. Prior to the main processing stage, the 9-band ASTER dataset was calibrated using the Internal Average Relative Reflectance method (IARR). In the main processing stage, basic spectrum and SID and LINE algorithms were used for identifying alteration effects (at a spatial resolution of $30 \mathrm{~m}$ in ENVI) and detecting lineation (at a spatial resolution of $15 \mathrm{~m}$ in Geomatica). Spectral Information Divergence (SID) is a spectral classification method which uses the degree of divergence between a known spectrum and unknown spectra to match the pixels with the reference spectra; the lower the divergence or difference, the more similar the pixels are. A threshold must be defined in this method; pixels values (digital numbers) greater than the threshold are not classified (Chang et al., 2004). The LINE algorithm is one of the most successful automated algorithms to detect lineation in images. By determining 6 factors including radial filter, the threshold slope of the lineation, the threshold of filling the lineation, the threshold of curvature, the threshold of angle difference, and the threshold of the line link length, this method determines the sensitivity of lineation extraction and extracts lineations (Canny., 1987).

\section{GEOLOGY OF THE STUDY AREA}

The study area is located at $51^{\circ} 16^{\prime} 58^{\prime \prime}$ east and $33^{\circ} 40^{\prime} 16^{\prime \prime}$ north, $130 \mathrm{~km}$ northeast of Isfahan and $5.5 \mathrm{~km}$ northeast of Kamoo village, Kashan province. According to Figure 1, the stratigraphic units of the region belong to the Paleozoic, Mesozoic, and Cenozoic eras. From a structural point of view, the region is located on an anticline structure with a northwest-southeast trend. The exposed part of the anticline consists of siltstone, sandstone, and Jurassic shale. This part is not exposed throughout the region and is limited to eroded areas. The rocks belonging to the Cretaceous formation are located below the Jurassic sedimentary formation as an unconformity (Bagheri., 1998, Khodami and Kamali Shervedani., 2018). Borna and Janesari (1993). The core of this anticline is considered to be the emergence site of granodiorite intrusive rocks and dikes with a dacite to andesite composition. The main trend of the anticline is parallel to the main fault of the Absard Valley and expands with a northeast-southwest trend (perpendicular to the geological structures in the Urmia-Dokhtar zone) (Borna \& Janessari, 1993, Zadmehr and Shahrokhi., 2019). Figure 1 shows the geological map of the Kamoo region. 


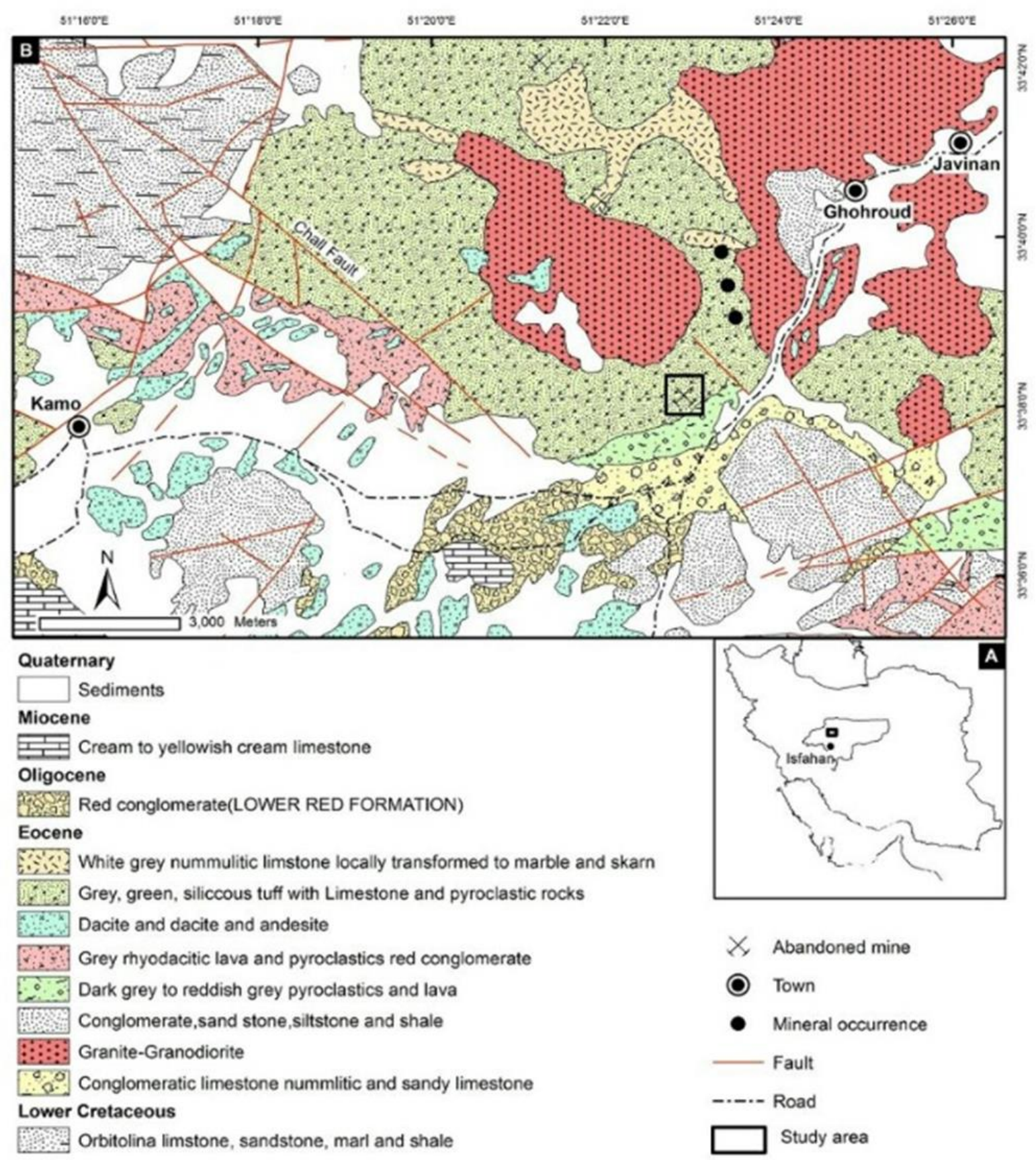

Figure 1. Geological map of the study area (Rokhbar et al., 2015).

\subsection{Shale unit - siltstone and Jurassic sandstone}

The Shemshak formation belongs to the Jurassic and has a relatively large extent. This formation borders the Triassic and contains shallow black shales and fine-grained sandstone layers of olive green to dark gray. The formation is located between limestone-shale layers with plant fossil fragments (Bagheri., 1998; Badr., 2012, Nazemi et al., 2019). This unit is the oldest exposed part of the Kamoo index (Figure 2-A). The rocks 
that make up this unit include siltstone-sandstone and shale with limestone layers. The lower part of the formation, which is the core of the Kamoo anticline, is mainly siltstone and sandstone (which have been converted to quartzite by alteration), and the upper part consists of dark shale with thin layers of limestone.

\subsection{Cretaceous unit}

In the study area, orbitolina limestones are located on top of the Jurassic formations as an unconformity (Bagheri, 1998) and begin with the Cretaceous base conglomerate (Figure 2-B). Due to its thinness and abundance of deposits, the Kamoo conglomerate unit has not been exposed; however, as we moves southwest (outside the exploration area), its thickness increases to about 40 to $60 \mathrm{~m}$. Although Cretaceous limestone formations form the upper part of the Kamoo index, it is not possible to determine their true thickness due to the activity of faults and erosive phenomena. In areas where the unit has come into contact with intrusive rock, skarn has formed (Figure 2-C). In general, the sequence of rocks from the Cretaceous includes limestone, shale, sandstone and marl, with orbitolina limestone units, sandy lime, marl and lower Cretaceous shale covering the largest extent (Figure D-2). These formations are located on top of the Jurassic sedimentary rocks as an unconformity due to the low-thickness conglomerate layer (Bagheri, 1998).
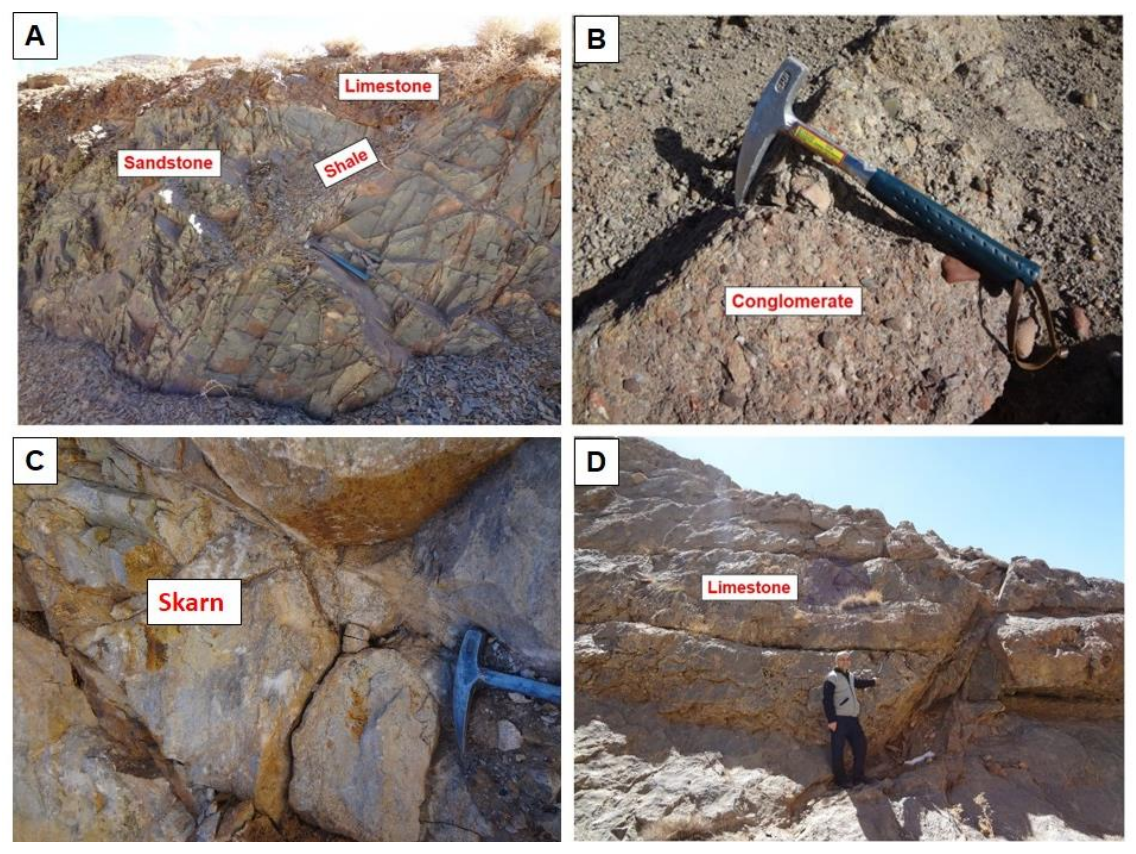

Figure 2. Units exposed in the Kamoo region: A) Sandstone exposure with layers of shale and lime, B)

Conglomerate exposure in the northern part of the region), C) Skarn formation in the limestones of the region (in the center of the region within the limits of the iron mine depot), D) The exposure of limestone and sandstone units in the Kamoo region (top of the image points to northeast).

\section{RESEARCH FINDINGS}

\subsection{Alteration effects}

All chemical and mineralogical changes in the host rock that occur under the influence of magmatic or hydrothermal waters are referred to as alterations (Karimpour and Saadat, 2003). Magmatic and 
hydrothermal deposits have their own alterational model. Deposits are usually concentrated in a special zone, which can be used in explorations (Gilbert and Park, 2007). The types of chemical and mineralogical changes that occur in rocks depend on the hydrothermal solution and the mineralogy and lithology of the surrounding rocks. The chemical composition of the hydrothermal or magmatic solution, temperature, depth, acidity, and oxidation-reduction conditions play an important role in alteration zones (Rose and Burt, 1979). Moreover, the intensity and extent of alteration halos are signs of the development of the mineralization process in promising mineral areas. The intensity and volume of mineralization depend on factors such as the volume of hydrothermal solutions, the number of useful primary and secondary structures, reactivity of rocks, and the temperature and pressure of the solution (Pirajno., 2009). Therefore, the relationship between alteration and mineralization is direct, and alteration zones are a good guide for determining the location of mineralization and its extent (Karimpour and Saadat, 2003).

During field studies in Kamoo, different types of alteration were identified, often located in areas of contact between granodiorite and Jurassic sedimentary formations (siltstone, sandstone, and shale) or Cretaceous formations (limestone). The results of XRD analysis confirmed the presence of montmorillonite, kaolinite, goethite, albite, quartz, and calcite, which is consistent with the results of petrographic studies and field observations. The most important alteration effects in the region are as follows.

\subsection{Sericitic Alteration}

Based on microscopic mineralogical studies, primary feldspars have been severely decomposed into sericite, quartz, and iron oxide (Figure 3-A). According to field observations, feldspar and plagioclase crystals have become sericites, which are seen in rock texture as filler in fractures. In some areas, sericites are oxidized by hematite and iron hydroxides (such as goethite) and their texture and color have changed. Due to hydrolysis, plagioclases have also changed into clay minerals and chlorite. Although this alteration is known by the co-occurrence of muscovite, quartz, chlorite, pyrite, and hematite, the percentage of pyrite is low in Kamoo's phyllic zones. This low percentage is due to the decomposition of pyrite to hematite and goethite in the presence of acidic solutions (the partial effects of euhedral and semi-euhedral can be seen in the sulfide section of this zone, which is not very extensive).

\subsection{Argillic Alteration}

Argillic alteration is characterized by the formation of clay minerals due to severe $\mathrm{H}^{+}$metasomatism and acid leaching at temperatures of 100 to $300{ }^{\circ} \mathrm{C}$. Most alkaline cations move out of the rock and small amounts of potassium, calcium, and magnesium remain, forming montmorillonite, illite, hydromica and chlorite. The collection of these minerals, with (or without) kaolinite, is known as average clay alteration. The influx of acidic fluids in some cases leads to the formation of kaolinite-dickite, pyrophyllite, and alunite, which indicate advanced clay alteration. The main sulfide mineral in clay alteration is pyrite (Neal et al., 2018). In the alteration units of Kamoo region, the oxidation of pyrites has led to the formation of goethite and limonite, resulting in the production of sulfuric acid, which has subsequently led to the acidic decomposition of plagioclases and feldspar into fine silica. Epidotization of plagioclases and increased water content of clay minerals indicate an early argillic phase and the onset of propylitic zone, which is consistent with our field observations. Figure 7-A shows argillic alteration in one of the samples.

\subsection{Hematitization}

This alteration occurs due to weathering of iron oxides, and its effects are seen in Kamoo as halos surrounding skarn. Small iron crystals also appear in the form of hematite, limonite, and goethite masses in some areas. The severity of alteration is so great in some cases that the primary rock is indistinguishable (Figure 3-C). The set is seen in bright to dark brown and reddish colors. Hydrothermal fluids from magmatic 
masses caused iron to release from iron-magnesium ores and deposit in the form of small irons along gaps under the right conditions of pressure, temperature, and oxygen fugacity.

Field observations showed that most of the plagioclase in this zone had changed into sericite and chlorite, and iron-magnesium minerals had been altered to iron and manganese oxides. Pyroxene is also completely altered to iron oxide and chlorite and is seen as iron oxides in rock texture. Hematitization may have occurred during martitization (surface decomposition of magnetite) (Figure 7-B). Martite is a pseudomorph magnetic mineral formed under conditions of high oxygen fugacity. Martitization is seen in epithermal to porphyry iron oxide copper gold (IOCG) deposits, and can be caused by changes in oxygen fugacity during magma cooling, alteration, or paleo-water (fossil) cycles during ore formation (Camprubí et al., 2016). Jarosite is present in the hydrothermal alteration zones. The presence of iron hydroxide $(\mathrm{Fe}-\mathrm{OH})$ increases the spectral absorption of this mineral, making identification possible (Bedini, 2011). (Absorption is observed at wavelengths of $0.482,0.807,2.26$, and $2.40 \mu \mathrm{m}$ and emission is observed at wavelengths of $0.66,1.65$, and $2.33 \mu \mathrm{m})$.

\subsection{Limonitization and goethitization}

Hydrothermal deposits may undergo surface alterations as well. On weathered surfaces, such masses are usually characterized by colors of yellow (limonite alteration index) and brown (goethite alteration index) (Figure 3-D). This surface discoloration is the result of development of hydromicas and kaolinite, and leaching of hydrated iron hydroxides by acids resulting from oxidation of sulfides. In supergene-reduction environments, iron(II) transfers in a dissolved form and iron(III) deposits as goethite (Barton and Johnson, 2000). Therefore, iron ores that dissolve in oxygen-rich near-surface environments during weathering form a rusty exposure surface rich in oxides and hydroxides of iron(III). In contrast, the subsurface solutions, subjected to reduction conditions (as observed in most hydrothermal fluids and water in some wells), contain iron(II) among the soluble compounds (Kesler, 1994).
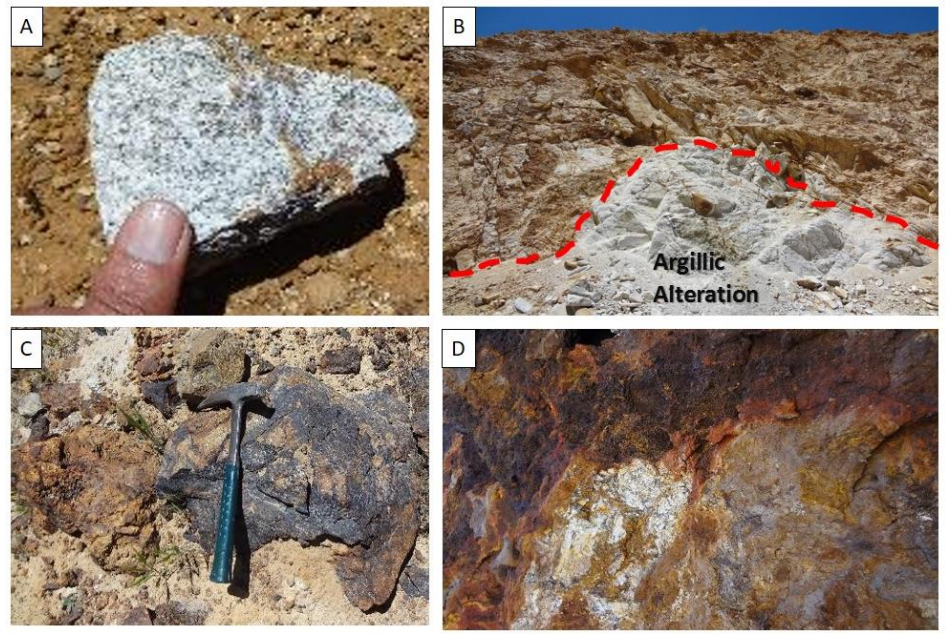

Figure 3. Exposure of alteration zones in the study area: A) Sericitization of primary rocks, B) Argilic alteration zone and accumulation of clay minerals and iron oxides, C) Hematite alteration, D) A close-up of Limonite and Goethite alteration.

Figure 4 shows the output of the SID model for detecting alteration of iron oxide. 


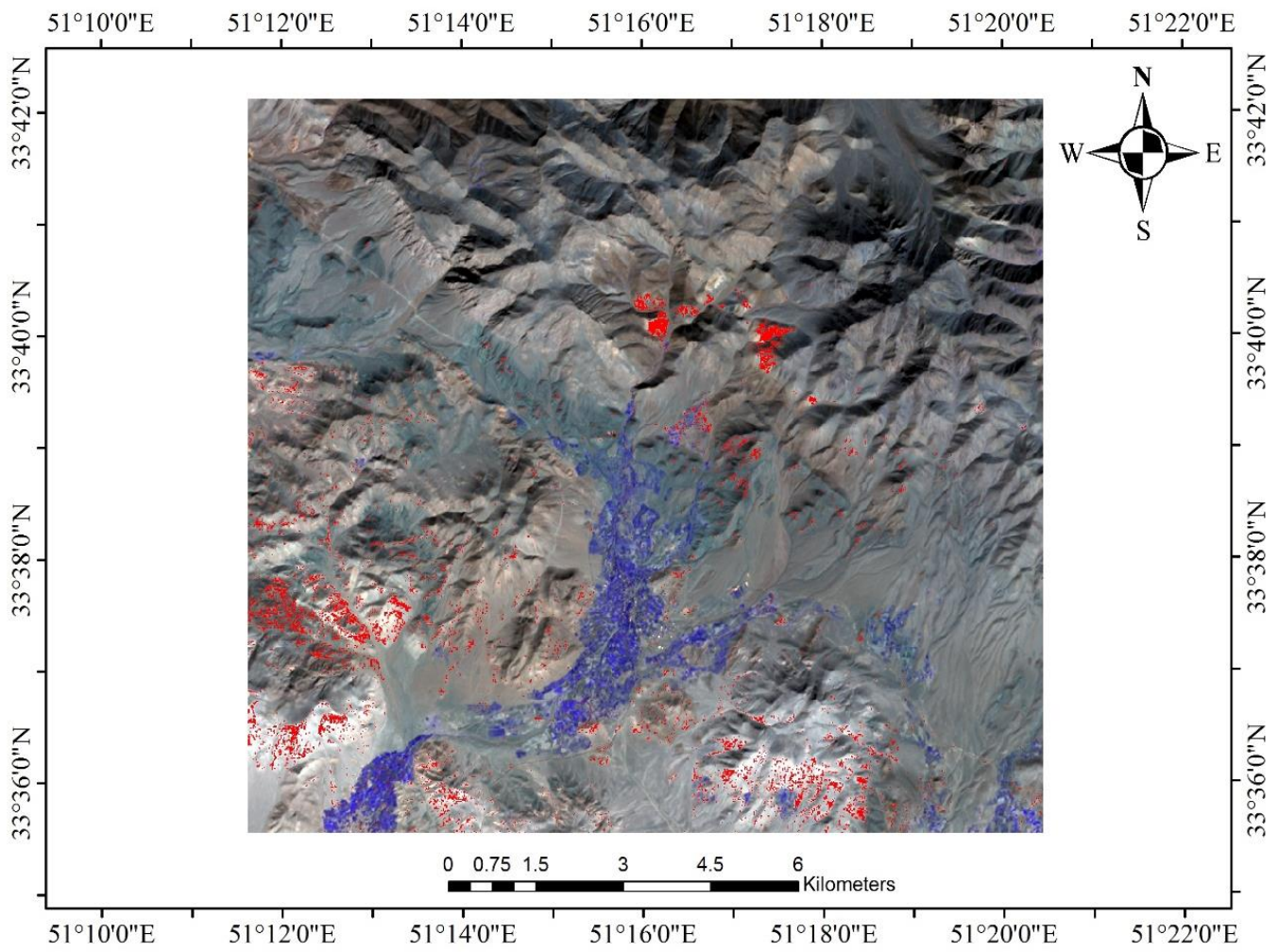

Figure 4. Detection of iron oxide alteration zones using the SID algorithm with jarosite as the index mineral. Red areas show the presence of jarosite. The background is a false color combination of bands 1, 2, and 3 from ASTER data. Blue areas indicate the presence of vegetation.

\subsection{Skarnization}

In the carbonate rocks of Kamoo region, high temperature alterations are associated with skarnization. This alteration is relatively extensive and consists of wollastonite, garnet, pyroxene, amphibole, mica, and clay minerals (Figure 5-A and Figure 7-C). According to our findings, the formation of iron ore in Kamoo coincided with the emergence of calcite skarns. We found the main metasomatic halo to be composed of garnet, pyroxene, amphibole, epidote, carbonate minerals, quartz, and magnetite. There is also a larger halo called the retrograde skarn which consists of calcite, chlorite, hematite, illite, montmorillonite, and pyrite. From an economic-geological point of view, iron skarns are the world's largest deposits of skarns (Minert., 1992); magnetite is the most important product of these deposits along with sub-mineralizations of gold, copper, nickel, and cobalt (Grigoryev., 1990). In the skarnization phase of Kamoo, we are confronted with another metasomatic phenomenon and the effects of hydrothermal alterations which have developed in the post-skarnization stage, especially in the vicinity of faults and crevices. In the endo-skarnization of Kamoo, the predominant phenomenon is metasomatic, and the further we move toward exo-skarnization, alteration becomes more prominent.

\subsection{Propylitization}

Propylitic minerals are formed during recrystallization and metasomatic metamorphosis of primary minerals of calcium and magnesium. From a petrographic point of view, this type of alteration is equivalent to green schist facies and consists of chlorite, epidote, and calcite (conversion of mafic minerals). Potassium from biotite and chlorite is transferred to sericite and remains stable during conversion of albite to anorthite (Beane and Titley., 1981; Pirajno., 2003). Sub-minerals related to this alteration include apatite, anhydrite, 
ankerite, and hematite (Neal et al., 2018). Epidote is one of the indicator minerals in this alteration and is formed as a secondary mineral under the influence of hydrothermal solutions. The absorption spectrum of this mineral is observed at wavelengths of 0.482 and $2.33 \mu \mathrm{m}$ due to the presence of iron and hydroxyl $(\mathrm{OH})$ ions, and its emission spectrum is observed at wavelengths of 2.16 and $2.40 \mu \mathrm{m}$ (Noori et al., 2019). Figure 6 shows the output of the SID algorithm for detecting propylitic alteration. There is a close spatial relationship between the effects of propylitic alteration and igneous rocks in the study area; an example of this is shown in Figure 7-D. As can be seen, the chlorite and epidote content in some exposures in the region are so high that the alteration facies have changed to chlorite-epidote (Figure 5-B).
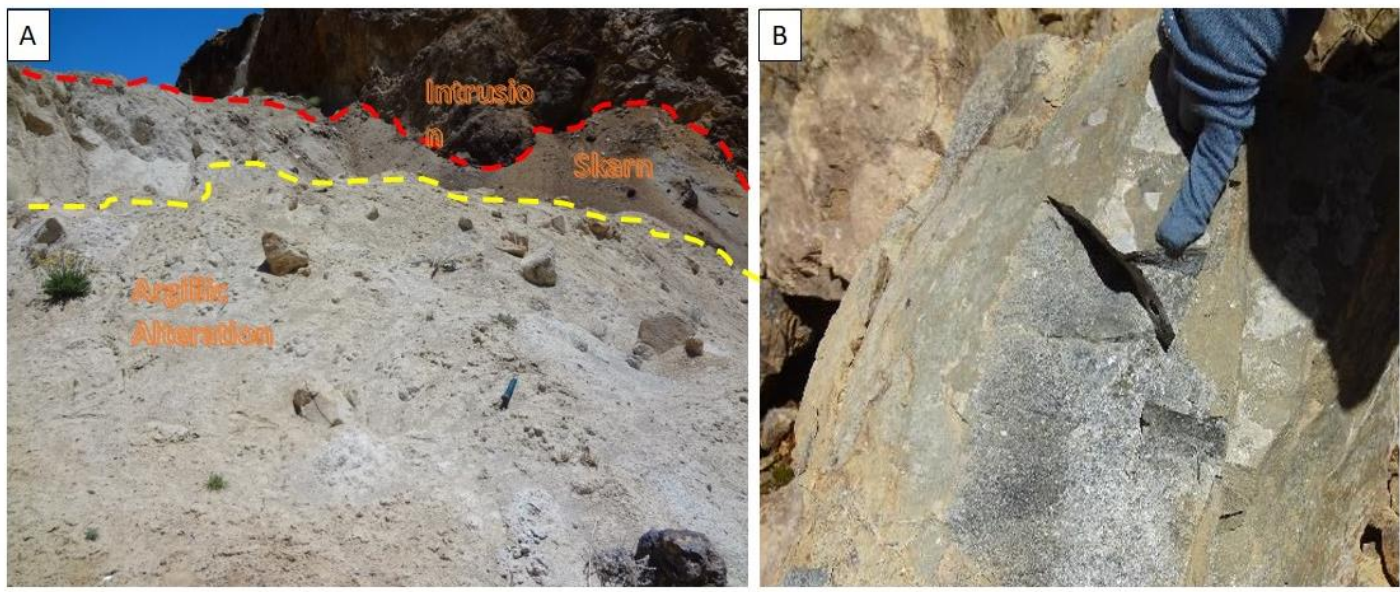

Figure 5. Exposure of alteration zones in the study area: A) Skarn and argilic alterations, B) Close view of propylitic alteration.

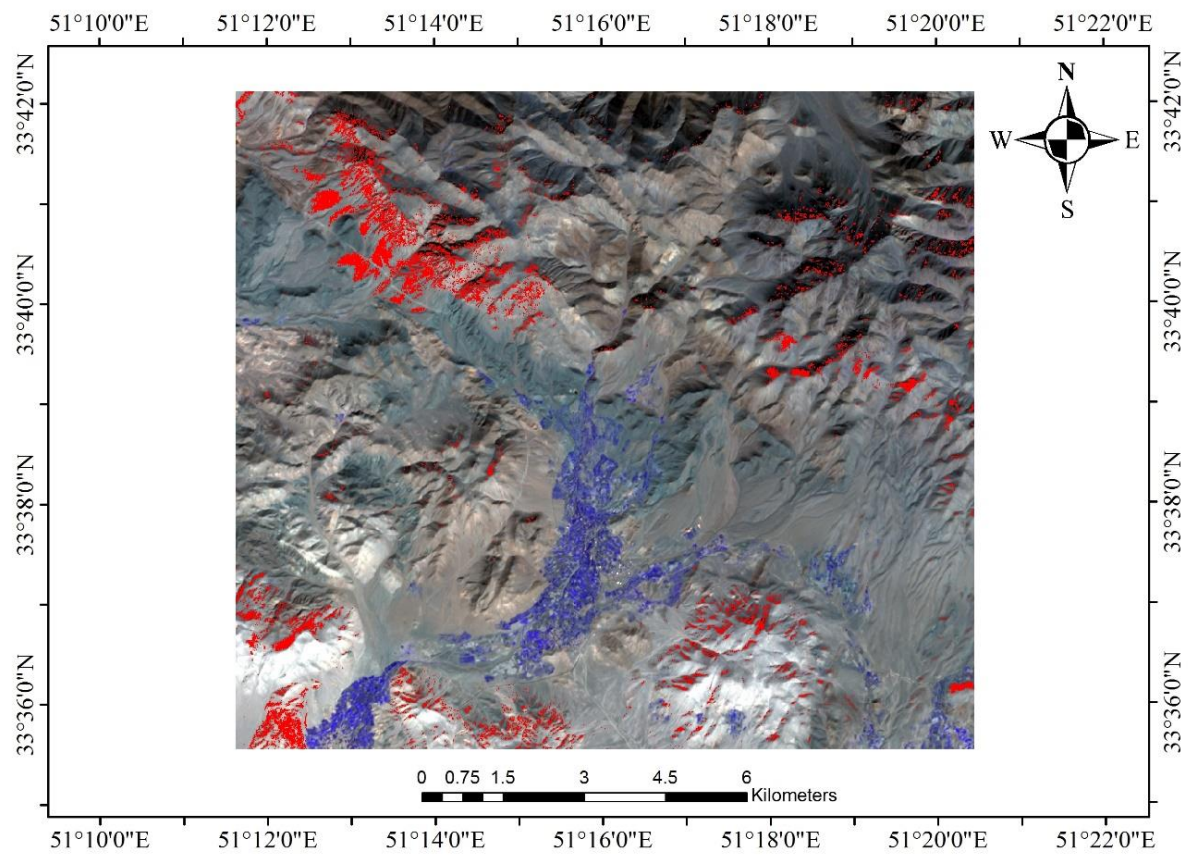

Figure 6. Detection of propylitic alteration zones using the SID algorithm with epidote as the index mineral. The red areas show the presence of epidote. The background is a false color combination of bands 1,2, and 3 from ASTER data. Blue areas indicate the presence of vegetation. 


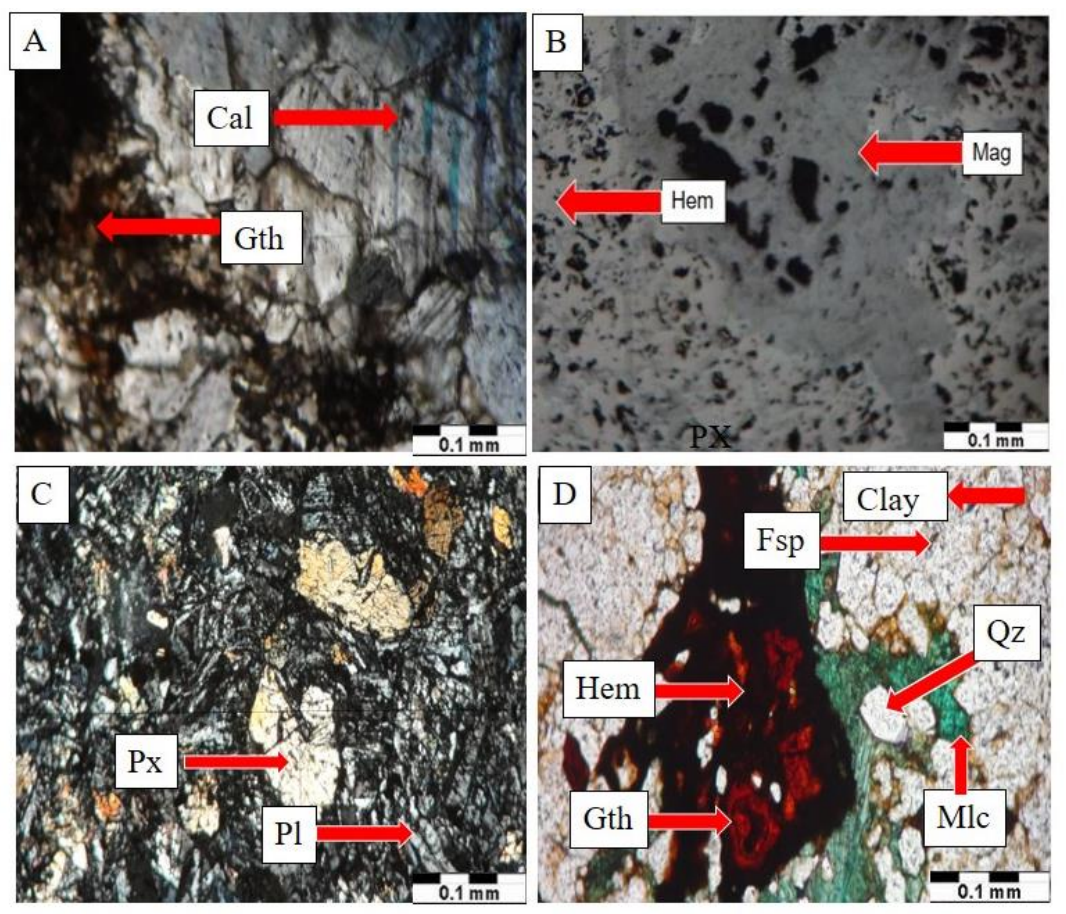

Figure 7. A) Presence of goethite (Gth) and calcite (Cal) in the propylitic zone, B) Martitization of magnetite (Mag) and formation of hematite (Hem), C) Skarnization and presence of plagioclase (Pl) and pyroxene (Px), D) Presence of clay minerals (Clay), feldspar (Fsp), quartz (Qz), hematite (Hem), goethite (Gth), and malachite (Mlc) in an argillic sample.

According to previous studies, the iron ore in Kamoo is a calcite skarn which contains metasomatic minerals such as garnet, pyroxene, amphibole, epidote, carbonates, quartz, and magnetite. Hematite, sericite, limonite, kaolinite, and propylitic alterations are also widely distributed. In addition to other metasomatic changes resulting from the granodiorite mass that caused the skarnization of the area, hydrothermal fluids have penetrated gaps and crevices, causing alterations. Changes in the supergene environment have also caused the weathering of iron sulfide ores and have created a leached cap (i.e., gossan).

The development of fractures has been an important factor for the passage of hydrothermal fluids and the control of hydrothermal-skarn mineralization in the study area. Therefore, in areas where fragmentation is evident, we see greater expansion and intensity of alteration, and as a result, mineralization has increased (hydrothermal alteration has intensified the process of iron ore formation in the skarn zone in Kamoo). In other words, wherever faults and gaps are abundant, the intensity of alteration has increased and the grade of iron skarn is higher.

\subsection{Tectonic setting of the host rock}

In this study, the $\mathrm{Rb}$ vs. $(\mathrm{Y}+\mathrm{Nb})$ discrimination diagram was used to determine the tectonic setting of the region (Pearce et al., 1984). Pearce et al (1984) divided rocks into four groups: the expansion zone (ORG), the continental collision zone (Syn-COLG), the intraplate zone (WPG), and the subduction zone (VAG). The diagram distinguishes Syn-collision rocks from volcanic-arc rocks. According to this method, there is a clear separation between intraplate and oceanic rocks. 


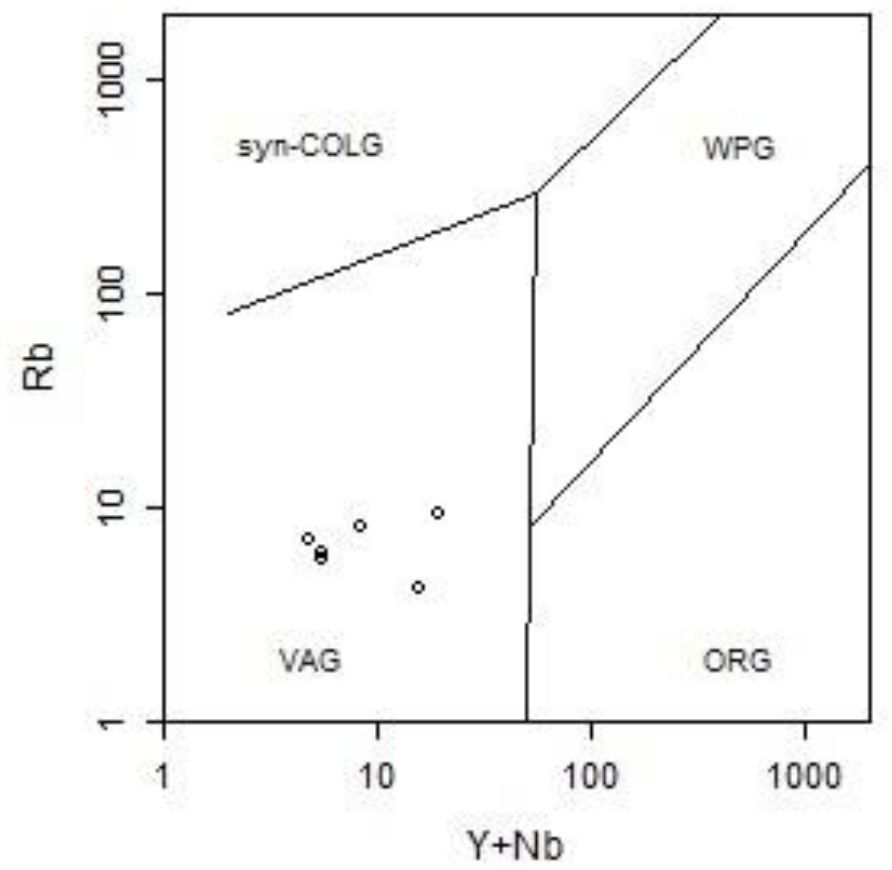

Figure 8. Determining tectonic setting using the $\log \mathrm{Rb}-\log (\mathrm{Y}+\mathrm{Nb})$ diagram.

Meinert (2005) has presented an updated categorization of tectonics which is more useful for determining the tectonic setting of skarn deposits. In this method, the convergence of skarn facies is considered as an indicator of the tectonic condition of deposits. According to Meinert's model, Kamoo iron skarn deposits have formed in oceanic subduction and back-arc basin environments.

\subsection{The relationship between tectonics and mineralization in Kamoo}

According to the results of this study and analysis of faults traced on satellite images (Figure 9) (Abdullah, 2013), the predominant trend of gaps and fractures in the region is such that the necessary conditions are provided for the penetration of magmatic masses and the passage of hydrothermal fluids (a northeastsouthwest trend). For example, the main fault of the Absard Valley has a northeast-southwest trend similar to other fractures in the Kamoo region (perpendicular to the axis of the anticline), and plays an effective role in the formation of penetrated and mineralized masses. The activity of fractures continued into the postskarn stage of Kamoo and caused the expansion of alteration halos, especially propylitic halos.

The multiplicity of fault structures and their northeast-southwest alignment indicates the existence of an extension phase similar to the skarnization trend of Kamoo. The extension phase has provided the necessary conditions for the emplacement of intrusive rocks prior to the mineralization. In addition, the magmatic activity of this region indicates the existence of intrusive masses with a granodiorite composition, which are mainly distributed in the center and west of the region. The intrusive masses are rarely exposed in the form of andesite dikes, in the west and southeast of Kamoo. The main host of iron skarn is Cretaceous limestone, and other formations such as Jurassic shale and siltstone are sub-hosts. In the Lower Cretaceous, we see the crystallization of limestone and the emergence of cream-to-brown marble, usually cut by iron oxide veins. Marble exposures are limited to the lower part of the Cretaceous and a significant volume of the limestone formations are under the influence of metasomatic, skarnization, and hyrothermal alterations. In terms of mineralization, there are three groups of minerals with different coexistence conditions. The first group 
includes garnet, pyroxene, pyrite, and magnetite. The hydrosilicates formed during alteration constitute the second group, and the collection of oxide minerals in the leached cap (hematite, limonite, and goethite) which are observed with scattered amounts of sulfide ores such as chalcopyrite and covellite make up the third group.

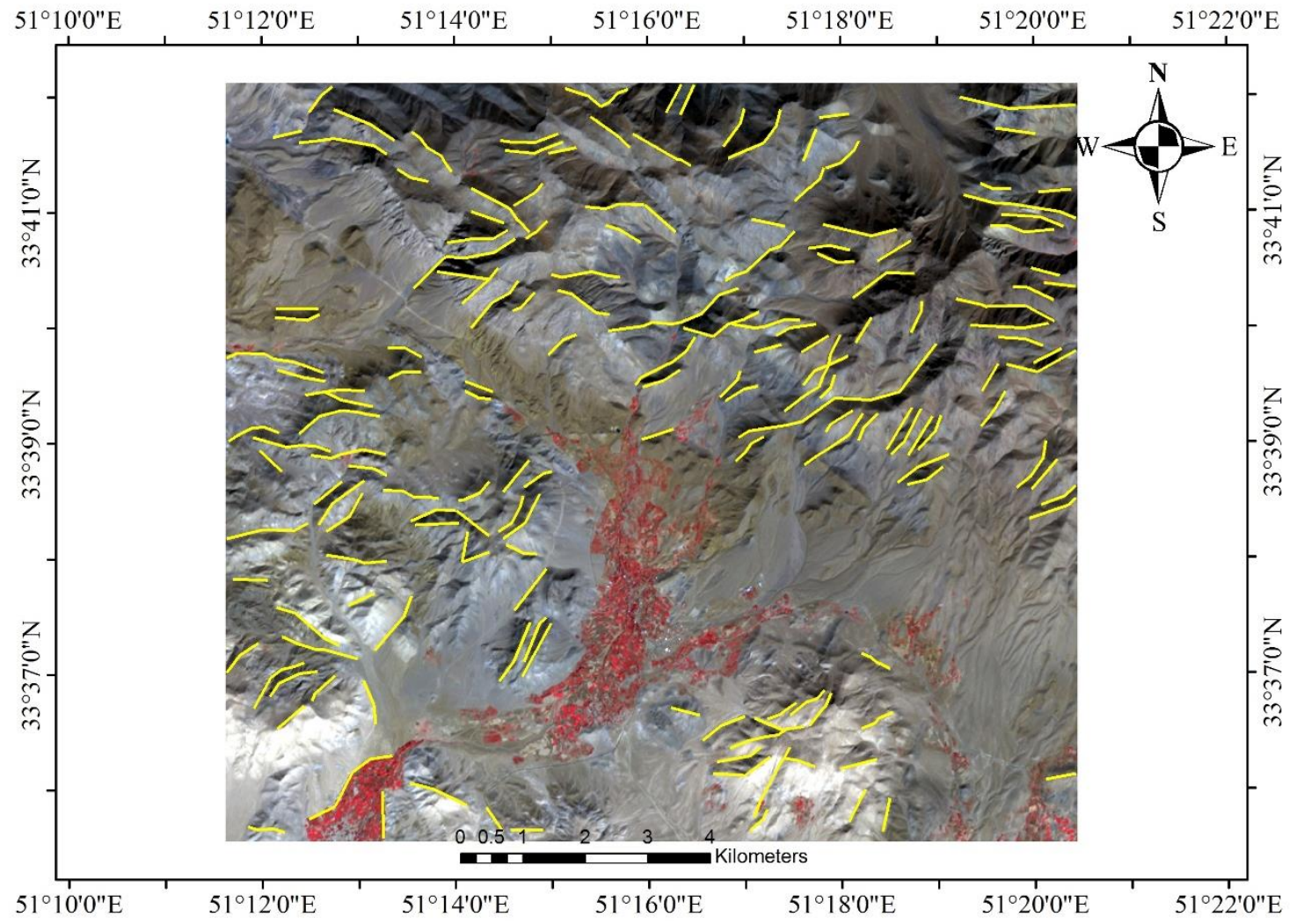

Figure 9. Tectonic lineation in the study area extracted using the LINE algorithm in PCI-Geomatica. Yellow lines in the image illustrate lineation. Accuracy of the output was confirmed by evaluating areas in Google Earth and randomly selecting and visiting $20 \%$ of lineations in the field.

\subsection{Geochemistry of rare-earth elements}

Rare-earth elements are often inactive and stable; therefore, they are not affected by alteration and metasomatic processes and are used to study the tectonic regime prevailing in promising mineral regions. Rare-earth elements are especially useful for the determination of the geochemical properties of magma (Lottermoser, 1992; Rollinson, 1993). The degree of mobility of these elements in magmatic and hydrothermal systems depends on factors such as $\mathrm{pH}$, Eh, available ligands, and temperature (Bi et al., 2002). The degree of mobility and separation of rare-earth elements are important in detecting magmatic processes such as crystalline separation, partial melting and magmatic mixing, identifying the source rock of magma and the various phases of mineralization-alteration, investigating the origin of the mineralizing fluid, and determining the tectonic environment (Winter, 2001). In order to study the geochemistry of rareearth elements, samples of iron ore and host rock were investigated based on the data provided by Boynton (1984), normality and degree of separation of rare-earth elements $(\mathrm{La} / \mathrm{Lu})_{\mathrm{N}}$, degree of separation of light rare-earth elements $(\mathrm{La} / \mathrm{Sm})_{\mathrm{N}}$, and degree of separation of heavy rare-earth elements $(\mathrm{Gd} / \mathrm{Lu})_{\mathrm{N}}$. Also, europium $(\mathrm{Eu})$ anomalies were studied according to the following equation: $\mathrm{Eu} / \mathrm{Eu}^{*}=\mathrm{Eu}_{\mathrm{N}} /\left[(\mathrm{Sm})_{\mathrm{N}}(\mathrm{Gd})_{\mathrm{N}}\right]^{1 / 2}$ 
(Figure 10). The results showed that in samples from Kamoo, the ratio of light rare-earth elements (LREEs) to heavy rare-earth elements (HREEs) had increased and the $(\mathrm{La} / \mathrm{Yb})_{\mathrm{N}}$ ratio had an average of 18.61, a minimum of 1.03, and a maximum of 40.48. Eu anomaly varied between 0.52 to 1.94. High REE content, high LREE/HREE ratio, and a weak Eu anomaly can be seen in Figure 10.

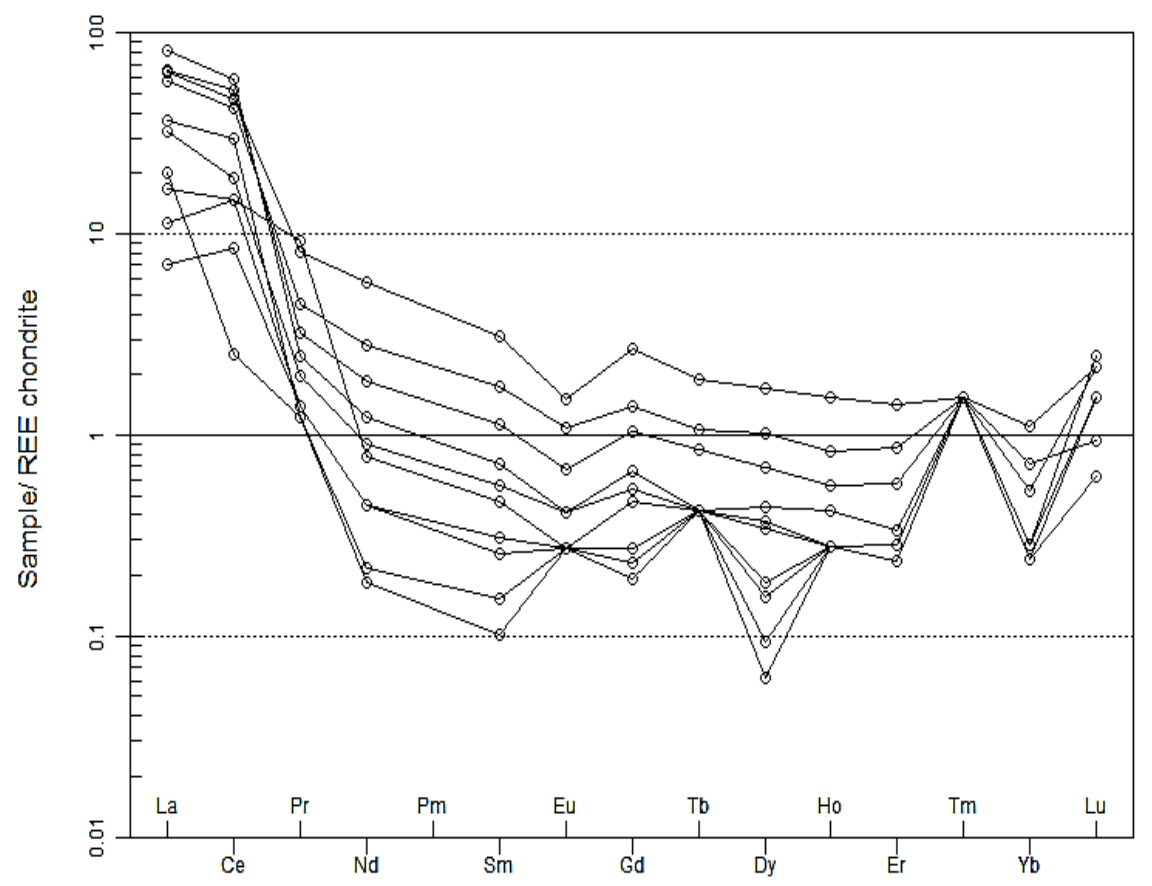

\begin{tabular}{|c|c|c|c|c|c|c|c|c|c|c|c|c|c|c|c|c|c|}
\hline & 2 as & CeN & PrN & $\mathrm{NdN}$ & $\mathrm{PmN}$ & $\mathrm{SmN}$ & EuN & $\mathrm{GdN}$ & $\mathrm{TbN}$ & DyN & $\mathrm{LN}$ & $\mathrm{ErN}$ & $\operatorname{TmN}$ & $\mathrm{YbN}$ & Lul & $\mathrm{Eu} / \mathrm{Eu} *$ & $\mathrm{LaN} / \mathrm{YbN}$ \\
\hline & 32.26 & 18.87 & 1.97 & 0.90 & $\mathrm{NA}$ & 0.56 & 0.41 & 0.54 & 0.42 & 0.37 & 0.28 & 0.29 & 1.54 & 0.24 & 0.62 & 4 & \\
\hline & .48 & 1.63 & 3.20 & 1.85 & A & .13 & 0.68 & .04 & 0.84 & .68 & 0.56 & 0.57 & 1.54 & 0.53 & 2 . & & \\
\hline 3. & 7.10 & 8.42 & 1.39 & 0.45 & A & .31 & 0.27 & .27 & 0.42 & 0.16 & 0.28 & 0.24 & 1.54 & 0.24 & 0. & & \\
\hline 3. & 11.29 & 14.76 & 1.39 & 0.45 & IA & .26 & 0.27 & 0.23 & 0.42 & 0.19 & 0.28 & 0.24 & 1.54 & 0.24 & 1.55 & 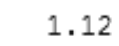 & 19 \\
\hline $\mathrm{J}$ & & 2.52 & 1.23 & 0.18 & A & .10 & 0.27 & 0.19 & 0.42 & 0.06 & 0.28 & 0.24 & 1.54 & 0.24 & 0. & & \\
\hline 11 & 77 & 29.73 & 1.23 & 0.22 & $\mathrm{JA}$ & .15 & 0.27 & 0.19 & 0.42 & 0.09 & 0.28 & 0.24 & 1.54 & 0.24 & 0.62 & 58 & .72 \\
\hline 11 & & & 4.51 & 2.77 & A & 74 & 1.09 & 1.39 & 1.05 & 1.02 & 0.84 & 0.86 & 1.54 & 0.72 & 0. & 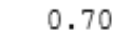 & \\
\hline 13 & 19 & 47.13 & 8.20 & 5.70 & $=1$ & .13 & 1.50 & 2.70 & 1.90 & 1.71 & 1.53 & 1.43 & 1.54 & 1.10 & $2.1^{\circ}$ & 1 & .33 \\
\hline 12 & & 14.93 & 9.18 & 0.78 & 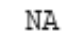 & .46 & 0.27 & 0.46 & 0.42 & 0.34 & 0.28 & 0.29 & 1.54 & 0.29 & 1. & & .43 \\
\hline 138 & 82.26 & 58.91 & 2.46 & 1.22 & $\mathrm{NA}$ & 0.72 & 0.41 & 0.66 & 0.42 & 0.43 & 0.42 & 0.33 & 1.54 & 0.29 & 2.48 & 0.59 & 286.53 \\
\hline
\end{tabular}

Figure 10. Diagram and table of the rare-earth elements in Kamoo deposit.

The features presented in Figure 10 are specific to continental-continental marginal tectonic regions. The magmatism of these regions is also related (Henderson, 1989). Eu anomaly, especially in felsic magmas, is under intermediate control by feldspars. Unlike other elements of the REE group, Eu also appears in a bivalent oxidation state and enters the network as an element compatible with the structure of plagioclase and potassium feldspar. Therefore, the presence of feldspar in the primary magma (due to melting) or its exit by fractional crystallization causes negative Eu anomaly. Amphibolite tholeiites contain low levels of REE which is still higher than that of intermediate magmas resulting from partial melting. Most models are 
based on the relative maximum and minimum ratio of the minerals in the source rock and the crystal-melt equilibrium during magma formation (Rollinson, 1993). The separation pattern of light and heavy rare-earth elements $(\mathrm{La} / \mathrm{Lu})_{\mathrm{N}}$ is usually expressed based on a factor called the distribution coefficient. This factor is widely used in geochemical studies of minor elements and explains the balance of minor elements in the mineral and the magma. The distribution coefficient is defined as follows (Equation 1):

\section{$\mathrm{Kd}=\mathbf{C m} / \mathbf{C M}$}

where $\mathrm{Kd}$ is the distribution coefficient, $\mathrm{Cm}$ is concentration of the element in the mineral, and $\mathrm{CM}$ is concentration of the element in the magma.

A distribution coefficient equal to 1 indicates that the element has the same distribution in the mineral and the magma. Values greater than 1 indicate that the minor element prefers the mineral phase, while values smaller than 1 indicate that the minor element prefers the magma. Table 1 presents the distribution coefficients of minerals for intermediate magmas according to Rollinson's database (1993). By controlling for the composition of REEs in different magmas, we can see that the distribution coefficient, the degree of separation of light and heavy elements, and LREE content increase as $\mathrm{SiO}_{2}$ content and felsiczation increase.

The presence of olivine, orthopyroxene, clinopyroxene, garnet, hornblende, and zircon in the solid and liquid phases is due to the high distribution coefficients of HREEs, which enriches the residual magma with LREEs. The distribution coefficient of $\mathrm{Lu}$ in minerals obtained from Kamoo is more than 1000 times that of La. Therefore, it is predicted that the primary mineral of the rocks is plagioclase, which has caused the negative anomaly of Eu in the magma. Melting of the primary source rock in the presence of amphibole, pyroxene, and garnet reduces the amounts of HREEs compared to LREEs in the remaining magma. Based on the composition of the intrusive igneous mass and the sulfide minerals, the samples taken from the intrusive rocks in Kamoo are in the iron skarn class.

Table1. Distribution partition coefficients of mineral per melt for intermediate magmas according Rollinson 1983.

\begin{tabular}{ccccccc}
\hline REE & Garnet & Plagioclase & Hornblende & Titanite & Orthopyroxene & Clinopyroxene \\
\hline La & 0.076 & $0.228-0.302$ & 0.500 & 2.000 & 0.031 & 0.047 \\
Ce & - & $0.136-0.221$ & - & - & $0.028-0.050$ & $0.084-0.508$ \\
Pr & - & - & - & - & & - \\
Nd & - & $0.115-0.149$ & $1.200-3.000$ & - & $0.028-0.047$ & $0.183-0.645$ \\
Sm & 1.250 & $0.077-0.117$ & - & 10.000 & $0.028-0.100$ & $0.337-0.954$ \\
Eu & 1.520 & $0.079-0.376$ & - & - & $0.028-0.12$ & $0.681-0.800$ \\
Gd & 5.200 & $0.050-0.067$ & - & - & $0.039-0.132$ & $0.583-1.350$ \\
Tb & 7.100 & - & - & - & - & - \\
Dy & - & $0.045-0.126$ & - & - & $0.076-0.212$ & $0.774-1.640$ \\
Ho & 23.008 & - & $1.500-3.000$ & 10.000 & & - \\
Er & - & $0.034-0.045$ & - & - & $0.153-0.314$ & $0.708-1.330$ \\
Tm & - & - & - & - & & - \\
Yb & 53.000 & $0.029-0.050$ & $1.200-2.100$ & - & $0.254-0.460$ & $0.633-1.300$ \\
Lu & 57.000 & $0.031-0.046$ & - & 6.000 & $0.323-0.464$ & 0.665 \\
\hline
\end{tabular}




\section{CONCLUSIONES}

The results of field studies, petrography, device analysis (XRD), and processing satellite images (ASTER data) are consistent and confirm the diversity of alteration effects and development of the mineralization process along fault structures and crushed areas. Most fractures associated with the penetration and placement of skarn masses had a northeast-southwest trend. Therefore, the distribution of faults and fractures in the Kamoo region was the effective factor for the passage of hydrothermal fluids and expansion of mineralization. Also, the type and severity of the alterations were influenced by tectonic activities in the area.

The alteration mechanism has been effective in the formation of high-grade iron-bearing masses in this area; iron masses were more concentrated wherever the intensity of alteration was high. In this region, iron ore was formed through calcite skarn. In the skarnization phase of Kamoo, metasomatic processes were involved, and in the post-skarn phase, hydrothermal effects were developed, especially in the vicinity of faults and crevices. In other words, in endo-skarnization of Kamoo, the predominant phenomenon is metasomatic and the further we move toward exo-skarnization, alteration becomes more dominant.

The origin of iron in Kamoo is a semi-deep acidic magma. The diffusion and movement of fluids toward upper horizons has given rise to limestone and dolomite skarnization, creating chlorite, hedenbergitic, zoisite, epidote, lipidcrolite, andradite, grossular, hessonite, and montmorillonite. In addition, hydrothermal fluids have caused the formation of alteration minerals such as kaolinite, montmorillonite, chlorite, and sercitic minerals. The supergene phenomenon has played a key role in enriching the iron ore, as evidenced by the leached cap. The Kamoo iron mine is located on gossan composed of magnetite, hematite, limonite, and goethite. Samples from Kamoo are richer in LREEs than HREEs, which shows the presence of calcite skarn in the region. It is recommended to conduct exploratory operations and geophysical exploration as well as investigating geophysical anomalies in the region.

\section{REFERENCIAS}

Anwar, A., Shawki, N., \& Ghaleeb., A. (2013). Landsat ETM-7 for lineament mapping using automatic extraction technique in the SW part of Taiz Area, Yemen. Global Journal of Human Social Science (B), XIII, 35-38.

B. Borna., Janessary, M. (1993). Systematic Discovery Plan Report of Exploration Operations on Map 1/100000 Kashan, (Persian).

Badr, A. (2012). Petrological studies of skarn from Eastern part of Ghohroud granodiorite (SE Ghamsar, Isfahan Province), M.Sc. Thesis. University of Isfahan, 157p, (Persian).

Bagheri, H. (1998). Preliminary discoveries and investigation of copper mineralization genesis in Kamo Mineral Index (Isfahan), Ph.D. Thesis, Kharazmi-University. 117p, (Persian).

Barton, M.D., \& Johnson, D.A., (2000). Alternative brine sources for Fe- oxide (-Cu- Au) systems: Implications for hydrothermal alteration and metals. In: T. M. Porter (Editor), Hydrothermal Iron Oxide Copper-gold and Related Deposits: A Global Perspective. V. 1, Australian Mineral Foundation Inc, Adelaide.

Beane, R. E., \& Titley, S. R. (1981). Porphyry copper deposits: Part II. Hydrothermal alteration and mineralization. Economic Geology. 75th Anniversary . 15, 235-269.

Bedini, E. (2011). Mineral mapping in the Kap Simpson complex, central East Greenland, using HyMap and ASTER remote sensing data. Advances in Space Research, 47, 60-73.

Bi, X., Cornell, D. H., \& Hu, R. (2002). REE composition of primary and altered feldspar from the mineralized alteration zone of alkaline intrusive rocks, western Yunnan province, China. Ore Geology Reviews, 19, 6978.

Camprubí, A., González-Partida, E., López-Martínez, M., Iriondo, A., Alfonso, P., Cienfuegos-Alvarado, E., Gutiérrez-Armendáriz, E., Morales-Puente, P., Canet, C., \& González-Ruiz, L. (2016). The Upper Cretaceous Guaynopa IOCG and Guaynopita porphyry copper deposits, Chihuahua, Mexico. Ore Geology Reviewsm, 81, Part 3, 1096-1112. 
Canny, J.F. (1987). A computational approach to edge detection, Readings in computer vision: issues, problems, principles, and paradigms. $184-203 \mathrm{p}$.

Chang, D., Ren, H., D’Amico, F.M., \& Jensen, J. (2004). New Hyperspectral Discrimination Measure for Spectral Characterization, Optical Engineering, 43, 1777-1786.

Fakhari, S., jafarirad, A., Afzal, P., \& Lotfi, M. (2019) Delineation of hydrothermal alteration zones for porphyry systems utilizing ASTER data in Jebal-Barez area, SE Iran, Iranian Journal of Earth Sciences, 11(1) pp 8092.

Grigoryev, N.A., Sazonov, V.N., \& Murzin, V.V. (1990). Sulfides as gold carriers in Skarn magnetite deposit Skarns and ores. Geochemistry International, 27, 142-146.

Guilbert, J. M., \& Park Jr, C. F. (2007). The geology of ore deposits. Waveland Press.

Henderson, P., (1989). Rare earth element geochemistry. Elsevier. 510 p.

Kesler, S. E., Jones, H. D., Furman, F. C., Sassen, R., Anderson, W. H., \& Kyle, J. R. (1994). Role of crude oil in the genesis of Mississippi Valley-type deposits: Evidence from the Cincinnati arch. Geology, 22, 609-612.

Khodami, M., \& Kamali Shervedani, A. (2018) Mineralogical and geochemical characteristics of the Chah-Shur clay deposit, Southeast of Isfahan, Iran, Iranian Journal of Earth Sciences, 10(2) pp 135-141.

Lottermoser, B. G. (1992). Rare earth elements and hydrothermal ore formation, Ore Geology Reviews, 7, 25-41.

Meinert, L. D. (1992). Skarns and Skarn deposits. Geoscience Canada, 19,145- 162.

Meinert, L. D., Dipple, G. M., \& Nicolescu, S. (2005).World skarn deposits. Economic Geology 100th Anniversary Volume, 299-336.

Najafzadeh, A., Khalili Mobarhan, Sh., \& Ahmadian, J. (2011). Economic Geology, Payam Nour University, Tehran, Iran, 409p, (Persian).

Nazemi, E., Arian, M.A., Jafarian, A., Pourkermani, M., \& Yazdi, A. (2019). Studying The Genesis Of Igneous Rocks In Zarin-Kamar Region (Shahrood, Northeastern Iran) By Rare Earth Elements. Revista Gênero e Direito, 8(4), 446-466. DOI: https://doi.org/10.22478/ufpb.2179-7137.2019v8n4.48442

Neal, L. C., Wilkinson, J. J., Mason, P. J., \& Chang, Z. (2018). Spectral characteristics of propylitic alteration minerals as a vectoring tool for porphyry copper deposits. Journal of Geochemical Exploration, 184, 179-198.

Noori, L., Pour, A. B., Askari, G., Taghipour, N., Pradhan, B., Lee, C. W., \& Honarmand, M. (2019). Comparison of Different Algorithms to Map Hydrothermal Alteration Zones Using ASTER Remote Sensing Data for Polymetallic Vein-Type Ore Exploration: Toroud-Chahshirin Magmatic Belt (TCMB), North Iran. Remote Sensing, 11, $495 \mathrm{p}$.

Pearce, J. A., Harris, N. B., \& Tindle, A. G. (1984). Trace element discrimination diagrams for the tectonic interpretation of granitic rocks. Journal of petrology, 25, 956-983.

Pirajno, F. (2009). Hydrothermal processes and mineral systems. Springer Science and Business Media.1250p.

Pirajno, F., Hawke, P., Glikson, A. Y., Haines, P. W., \& Uysal, T. (2003). Shoemaker impact structure, Western Australia. Australian Journal of Earth Sciences, 50, 775-796.

Rokhbar, M., Sharifi, M., \& Qishlaqi, A. (2015). Concentration Survey of Lead, Zinc, Cadmiom, Selenium in Natural Herbs around the Lead and zinc Mine of Amrood Valley Ghohrood, South Kashan. 33rd National Geosciences Symposium, Tehran, Iran, (Persian).

Rollinson, H.R. (1993). Using geochemical data: evolution presentation, interpretation. London, UK. 652 P.

Rose, A. W., \& Burt, D. M. (1979). Hydrothermal alteration, In: Barnes, H. L. (Ed)., Geochemistry of Hydrothermal Ore Deposits, John Wiley and Sons, New York, $173-227$ p.

Winter, O. (2001). An introduction of igneous and metamorphic petrology. Department of Geology Whitman College. $697 \mathrm{p}$.

Yazdi, A., Ashja Ardalan, A., Emami, M. H., Dabiri, R., \& Foudazi, M. (2019) Magmatic interactions as recorded in plagioclase phenocrysts of quaternary volcanics in SE Bam (SE Iran), Iranian Journal of Earth Sciences, 11(3) pp 215-225.

Zadmehr, F., \& Shahrokhi, S. V. (2019) Separation of geochemical anomalies by concentration-area and concentrationnumber methods in the Saqez 1:100,000 sheet, Kurdistan, Iranian Journal of Earth Sciences, 11(3) pp 196204. 